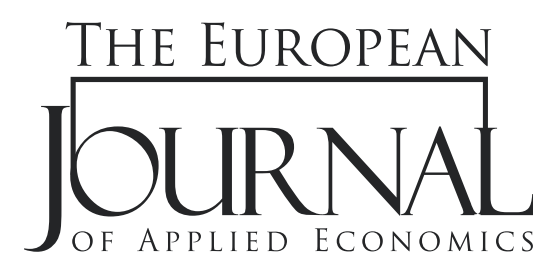

EJAE 2020, 17(2): 147 - 160

ISSN 2406-2588

UDK: 331.5(497-15)"2003/2017"

DOI: $10.5937 /$ EJAE17-25663

Original paper/Originalni naučni rad

\title{
FDI INFLOW EFFECTS ON WESTERN BALKAN AREA'S LABOUR MARKETS
}

\author{
Milica Perić*, Nemanja Stanišić
}

Singidunum University,

Belgrade, Serbia

\begin{abstract}
:
Labour market dependency on Foreign Direct Investments (FDI) inflow is very high in transition economies. This paper estimates the effects of FDI inflow on the employment rate and average net wages in Western Balkan economies in the period 2003-2017. The sample of economies (Albania, Bosnia and Herzegovina, Croatia, North Macedonia, Montenegro, and Serbia) was selected mainly because of the high legacy with FDI and unsaturated labour market. Presumably, FDI inflow has a positive impact on the employment rate and on average net wages in the Western Balkan countries. Employing linear mixed-effects models (LMM), the results indicate that FDI inflow changes have very low but positive and significant effects on both the changes in employment rate and on average net wages.
\end{abstract}

Article info:

Received: March 11, 2020

Correction: April 13, 2020

Accepted: July 31, 2020

\section{Keywords:}

average net wage, employment rate, foreign direct investments, linear mixed model, random effects.

\section{INTRODUCTION}

During the last few decades, Foreign Direct Investments (FDI) have grown rapidly worldwide, although the global flow of FDI in developing countries decreased in 2017 (UNCTAD, 2018). As FDI is labelled as the key factor in global economic development, growth, and integration (Bitzenis \& Marangos, 2007), it has also been adopted as a vital strategy for the development of economies in transition (Dabla-Norris et al., 2010). International trade acceleration and fast technological development, along with the global FDI, tend to change the aspect of national and local economies (Kekic, 2011). Besides the positive technological and knowledge spill-overs of FDI inflow by multinationals (MNEs), FDI inflow stimulates the productivity and the opening of the economy (import/export) of the host country (Peric \& Filipovic, 2018). However, Krammer (2010) proved that the FDI inflow has a lower impact on productivity than the trade inflow. 
Additional capital, an improved business and investment climate, job creation, innovative infrastructure, technology transfer, improving national branding, etc., are the benefits of FDI inflow reflected in the host countries (Szondi, 2007; Nikolic \& Bodroza, 2012; Melnyk, Kubatko \& Pysarenko, 2014). According to Tanna, Li \& De Vita (2018), however, high external debt constrains developing host countries from gaining benefits from FDI. From the other side, the debate about the impact of FDI inflow on labour markets in transition economies is still open. Perhaps the FDI inflow stimulates job creation more in developed countries than in developing and transition countries, mainly because of the availability of a skilled labour force and market composition.

The Western Balkan countries are emerging democracies that have been engaged in many aspects of globalization during the last decades (Bartlett, 2007; Bukowski, 2005). According to Todorova (2018), FDI inflow in the Balkans reveals the influence of contemporary global capitalism. FDI was found to be suitable for battling the national economic dysfunction and recession, as well as to accelerate the development and economic growth (Chandler, 2007). Analysing the impact of transition and of political instability on FDI inflow to the Balkans countries, Brada et al. (2006) found that instability and conflicts in these countries reduce FDI inflow, causing the delay in transition. In the transition national economies, the inflow of FDI occurred mainly in the form of mergers and acquisitions (M\&A) in order to stimulate the national markets and privatisation of public companies and bankrupted public and private enterprises (Estrin \& Uvalic, 2013; UNCTAD, 2011).

As concerns the countries under examination, Neto, Brandao \& Cerqueria (2008) claim that greenfield investment had a positive effect on economic growth in all countries, but that M\&A had a negative effect on developing countries in the period 1996-2006. Savic, Barjaktarovic \& Konjikusic (2014) proved that cross-border credits per capita ( $\mathrm{CBCpc}$ ) represent the most important inflow of foreign capital, with the correlation coefficient of gross domestic product per capita (GDPpc)/CBCpc in the period 2005-2010 as follows: Serbia $r=0.917$, Croatia $\mathrm{r}=0.949$, Montenegro $=0.849$, and $\mathrm{BiH}=0.733$. Pitic et al. (2014) confirmed these outcomes, i.e., the positive and significant impact of CBCpc inflow on GDPpc.

Even as one of the key factors of globalisation (OECD, 2008), and the crucial factor for development of the Balkans (Kekic, 2006), FDI inflow creates employment and wage discrepancies. In relation to this statement, the object of this research is to measure the effects of FDI inflow on labour market key indicators, i.e., employment rate and average net wages. To the best of the authors' knowledge, the relationships between FDI inflow and the abovementioned labour market indicators in the representative countries in examination have not been tested as of yet, and this research is about to cover this gap in the literature. The other reason for selecting this sample of countries is because of its long legacy with FDI (Hadzic \& Pavlovic, 2011).

The motivation for analysing the relationship between FDI inflow and labour market indicators is the high sensitivity of labour market indicators to FDI inflow, in particular because of the non-saturation of the labour market in Western Balkan countries. Indeed, unlike in highly developed economies, there is more room for FDI in the countries under examination, mainly in those still in transition. Furthermore, FDI inflow in the Western Balkan area may have a strong impact on changes in GDP, which is not the case for highly developed economies.

The aim of this paper is to measure the impact of FDI inflow percentage point changes on percentage point changes in the employment rate and on percentage point changes in average net wages in the Western Balkan area representative countries in the period 2003-2017. The expected overall results are the low positive and significant effects of FDI inflow on both the employment rate and average net wages.

The subsequent part of this paper provides a review of the relevant academic literature regarding the impact of FDI on the labour market. The third part consists of the data and applied econometric models' presentation. The fourth section shows the estimation and the interpretation of the results. The last part provides an overview of the research results and several recommendations. 


\section{LITERATURE REVIEW}

Recent empirical research and projects have shown efforts to analyse the impact of FDI inflow on a host country's economic arena and its implications for the labour market. Nevertheless, the FDI inflow contributes to the intensification of economic development and national competitiveness of the Western Balkan economies (Vesaite, 2014) The labour market differences are recognizable.

Table 1 consists of eleven empirical studies on the impact of FDI on the labour market segments and six additional studies of the effect of FDI on wage inequality, which have been chosen as representative studies for the approaches used, and the results found.

Table 1. Impact of FDI on Labour Market Indicators - Empirical Studies

\begin{tabular}{|c|c|c|c|}
\hline Author(s) & Methodology & $\begin{array}{l}\text { The Effect of Interest and } \\
\text { Geographical Scope }\end{array}$ & Results \\
\hline $\begin{array}{l}\text { Gopinath \& } \\
\text { Chen }(2003)\end{array}$ & OLS regression & $\begin{array}{l}\text { Impact of FDI inward on } \\
\text { wages in } 26 \text { countries }\end{array}$ & $\begin{array}{l}\text { FDI inward was found to have a negative } \\
\text { effect on wage inequality }\end{array}$ \\
\hline $\begin{array}{l}\text { Taylor \& } \\
\text { Driffield } \\
(2005)\end{array}$ & $\begin{array}{l}\text { Fixed-effects and } \\
\text { GMM estimators }\end{array}$ & $\begin{array}{l}\text { Impact of FDI inward on } \\
\text { manufacturing industries } \\
\text { shifts in demand towards } \\
\text { higher skilled labour in UK }\end{array}$ & $\begin{array}{l}\text { FDI inward was found to have a negative } \\
\text { effect on wage inequality }\end{array}$ \\
\hline $\begin{array}{l}\text { Figini \& Gorg } \\
(2006)\end{array}$ & $\begin{array}{l}\text { Fixed-effects and } \\
\text { GMM estimators }\end{array}$ & $\begin{array}{l}\text { Impact of FDI inward on } \\
\text { wage inequality in } 103 \\
\text { countries }\end{array}$ & $\begin{array}{l}\text { FDI inward was found to have a negative } \\
\text { effect on wage inequality in developing } \\
\text { countries, and a positive effect in } \\
\text { developed countries }\end{array}$ \\
\hline $\begin{array}{l}\text { Bhandari } \\
(2007)\end{array}$ & OLS regression & $\begin{array}{l}\text { Impact of FDI on wage } \\
\text { inequality in transition } \\
\text { countries }\end{array}$ & $\begin{array}{l}\text { FDI was found to have a positive effect } \\
\text { on average wages, and a negative effect } \\
\text { on wage inequality }\end{array}$ \\
\hline Stanisic (2008) & $\begin{array}{l}\text { Correlation } \\
\text { analysis }\end{array}$ & $\begin{array}{l}\text { Impact of FDI on economic } \\
\text { growth in South European } \\
\text { transition countries }\end{array}$ & $\begin{array}{l}\text { FDI was found to have a positive effect } \\
\text { on employment }\end{array}$ \\
\hline $\begin{array}{l}\text { Driffield et al. } \\
(2010)\end{array}$ & GMM estimators & $\begin{array}{l}\text { Impact of FDI inward on } \\
\text { wage inequality in UK }\end{array}$ & $\begin{array}{l}\text { FDI inward nationally tends to increase } \\
\text { wage inequality, while the local FDI } \\
\text { inward tends to decrease wage inequality }\end{array}$ \\
\hline Halmos (2011) & OLS regression & $\begin{array}{l}\text { Impact of FDI inward on } \\
\text { wage inequality in CEE }\end{array}$ & $\begin{array}{l}\text { FDI inward was found to have a negative } \\
\text { effect on wage inequality }\end{array}$ \\
\hline $\begin{array}{l}\text { Sabic et al. } \\
(2012)\end{array}$ & $\begin{array}{l}\text { Correlation } \\
\text { analysis }\end{array}$ & $\begin{array}{l}\text { Impact of FDI inflow on } \\
\text { unemployment in Serbia }\end{array}$ & $\begin{array}{l}\text { FDI inflow was found to have no significant } \\
\text { effect on unemployment }\end{array}$ \\
\hline Zulfiu (2014) & $\begin{array}{l}\text { Simulation } \\
\text { analysis }\end{array}$ & $\begin{array}{l}\text { Impact of FDI inflow on } \\
\text { wage inequality in transition } \\
\text { countries }\end{array}$ & $\begin{array}{l}\text { FDI inflow was found to have a positive } \\
\text { effect on domestic skilled wages, and } \\
\text { negative effect on unskilled wages }\end{array}$ \\
\hline $\begin{array}{l}\text { Kurtovic, } \\
\text { Talovic, \& } \\
\text { Dacic }(2015)\end{array}$ & OLS regression & $\begin{array}{l}\text { Impact of FDI inflow on } \\
\text { average net wages in Bosnia } \\
\text { and Herzegovina, } \\
\text { Montenegro, Macedonia } \\
\text { and Serbia. }\end{array}$ & $\begin{array}{l}\text { FDI inflow was found to have a positive } \\
\text { effect on net average wages }\end{array}$ \\
\hline $\begin{array}{l}\text { Domazet } \\
(2016)\end{array}$ & $\begin{array}{l}\text { Case study: } \\
\text { analytical } \\
\text { approach }\end{array}$ & $\begin{array}{l}\text { Impact of FDI on economic } \\
\text { growth in Bosnia and } \\
\text { Herzegovina }\end{array}$ & $\begin{array}{l}\text { FDI was found to have a partial positive } \\
\text { effect on employment rate in Bosnia and } \\
\text { Herzegovina }\end{array}$ \\
\hline
\end{tabular}




\begin{tabular}{|c|c|c|c|}
\hline $\begin{array}{l}\text { Jude \& Silaghi } \\
(2016)\end{array}$ & $\begin{array}{l}\text { Fixed-effects and } \\
\text { GMM estimators }\end{array}$ & $\begin{array}{l}\text { Impact of FDI on } \\
\text { employment in CEE }\end{array}$ & $\begin{array}{l}\text { FDI was found to have a short-term } \\
\text { negative effect and a long-term positive } \\
\text { effect on employment }\end{array}$ \\
\hline $\begin{array}{l}\text { Hale \& Xu } \\
(2016)\end{array}$ & Causality test & $\begin{array}{l}\text { Impact of FDI in host } \\
\text { countries }\end{array}$ & $\begin{array}{l}\text { FDI was found to have a positive effects } \\
\text { on labour markets (labour force } \\
\text { composition, employment, average } \\
\text { productivity, wage levels, and wage } \\
\text { inequality) in host countries }\end{array}$ \\
\hline $\begin{array}{l}\text { Zdravkovic } \\
\text { \& Martinovic } \\
(2016)\end{array}$ & OLS regression & $\begin{array}{l}\text { Impact of FDI on } \\
\text { unemployment in } \\
\text { transition countries }\end{array}$ & $\begin{array}{l}\text { FDI was found to have no significant } \\
\text { effect on unemployment }\end{array}$ \\
\hline $\begin{array}{l}\text { Grahovac \& } \\
\text { Softic (2017) }\end{array}$ & OLS regression & $\begin{array}{l}\text { Impact of FDI inflow on } \\
\text { the unemployment rate in } \\
\text { the West Balkan countries }\end{array}$ & $\begin{array}{l}\text { FDI inflow was found to have no } \\
\text { significant effect on unemployment }\end{array}$ \\
\hline $\begin{array}{l}\text { Popovic \& Eric } \\
(2018)\end{array}$ & Causality test & $\begin{array}{l}\text { Impact of EU FDI inflow } \\
\text { on Western Balkan } \\
\text { economies }\end{array}$ & $\begin{array}{l}\text { EU FDI inflow was found to have no } \\
\text { significant effect on unit labour costs }\end{array}$ \\
\hline Peric (2019) & OLS regression & $\begin{array}{l}\text { Impact of FDI inflow on } \\
\text { employment and on average } \\
\text { wages in Serbia }\end{array}$ & $\begin{array}{l}\text { FDI inflow was found to have no significant } \\
\text { effect on increase in employment or } \\
\text { average wages }\end{array}$ \\
\hline
\end{tabular}

Source: Authors' preparation

According to Table 1, there is evidence of both positive and negative impact of FDI on the indicators of the labour market. Hale \& Xu (2016) claim that there is an overall positive effect of FDI on the host countries labour market. According to them, FDI is responsible for the increase in wage inequality, as well, mostly due to the workers' skill levels. Whilst Sabic et al. (2012), Zdravkovic \& Martinovic (2016), Grahovac \& Softic (2017), and Peric (2019) found that there is no significant impact of FDI inflow on employment, Stanisic (2008), and Jude \& Silaghi (2016) claim that FDI inflow has a positive impact on employment growth. Similarly, Domazet (2016) stresses that FDI inflow represents only a partial contribution to employment rate growth.

As far as average wages are concerned, Bhandari (2007) and Kurtovic, Talovic \& Dacic (2015) claim that there is an increase due to FDI inflow. Moreover, Kurtovic et al. (2015), by applying the Variance Decomposition Test (VDT), predicted that the growth of average net wages will lead to increased FDI inflow over the next ten years, but that the increase in FDI inflow will not have a significant effect on average net wages. As concerns the EU FDI inflow in Western Balkan economies, there is no significant effect on unit labour costs (Popovic \& Eric, 2018).

In general, FDI appear to have a slightly positive effect on the employment rate and on average net wages in transition countries. However, FDI inflow tends to increase wage inequality, as Gopinath \& Chen (2003), Taylor \& Driffield (2005), Figini \& Gorg (2006), Driffield et al. (2010), Halmos (2011), and Zulfiu (2014), have proved. Whilst foreign companies and MNEs tend to employ more highly skilled labour, the unexpected pay gap between domestic and foreign companies may reflect the difference between the demand for employees' ability and skills. The homogenous results from the empirical literature show that companies under foreign ownership pay higher wages and require a skilled labour force.

On the basis of the literature background, the overall impact of FDI inflow on Western Balkan area representative countries remained unknown, despite previous research. This study covers this gap in the literature, and contributes to the knowledge about the effects of FDI inflow on the chosen labour market indicators in the countries under examination.

The following section presents the data used for modelling and the econometric methodology. 


\section{DATA AND MODEL SPECIFICATION}

This section presents the quantitative variables, a description of the data used for the analysis in the first subpart, and the specification of the chosen statistical models and the statement of the hypotheses in the second subpart.

\section{DATA}

For modelling FDI inflow in relation to the employment rate and average net wages in Western Balkan area representative economies, data was derived from secondary sources. Therefore, the panel data for the period 2003-2017 is constructed with the information obtained from: a) Balance of payments (retrieved from the official site of each country's national bank in the statistical database for FDI inflow), and b) Labour market section (retrieved from the official site of each country's statistical office for both the employment rate and average net wages).

A description of the variables used in directing this research is presented in Table 2 for all six Western Balkan countries (Albania, Bosnia and Herzegovina - BiH, Croatia, Macedonia, Montenegro, and Serbia), along with the source and the official methodology for calculating and presenting the data.

Table 2. Description of Variables According to Data from Official Sources

\begin{tabular}{llll}
\hline & \multicolumn{1}{c}{ FDI Inflow } & Employment Rate & Average Net Wage \\
\hline Country/Unit of measure & million EUR, per year & average per year (age +15) & EUR, per year \\
\hline Albania & BA/BoP BPM6 & INSTAT SURVEY & INSTAT SURVEY \\
BiH & CBBH/BoP BPM6 & BHAS SURVEY & BHAS SURVEY \\
\hline Croatia & HNB/BoP BPM6 & DZS SURVEY & DZS SURVEY \\
\hline North Macedonia & NBRM/BoP BPM6 & MAKSTAT SURVEY & MAKSTAT SURVEY \\
\hline Montenegro & CBCG/BoP BPM6 & MONSTAT SURVEY & MONSTAT SURVEY \\
\hline Serbia & NBS/BoP BPM6 & RZS SURVEY & RZS Tax admin. \\
\hline
\end{tabular}

Note: the amounts in EUR are at current prices. Official values in convertible marks for BiH and Albanian Lek are converted into EUR in accordance with BiH's CBBH and Albania's BA official yearly base exchange rate, respectively.

Source: Authors' preparation

where:

BA - Bank of Albania, CBBH - Central Bank of Bosnia and Herzegovina, HNB - Croatian National Bank, NBRM - National Bank of the Republic of Macedonia, CBCG - Central Bank of Montenegro, NBS - National Bank of Serbia, INSTAT - Institute of Statistics of Albania, BHAS - Agency for Statistics of Bosnia and Herzegovina, DZS - Croatian Bureau of Statistics, MAKSTAT - State Statistical Office of Republic of Macedonia, MONSTAT - Statistical Office of Montenegro, RZS - Statistical Office of the Republic of Serbia, BoP - Balance of Payments, BPM6 - Methodology of calculation by OECD (2008).

Table 3 shows the descriptive statistics for each factor taken into consideration for the modelling. 
Table 3. Descriptive Statistics

\begin{tabular}{|c|c|c|c|c|c|c|c|c|}
\hline \multicolumn{9}{|c|}{ Descriptive Statistics } \\
\hline & $\mathrm{N}$ & Range & $\begin{array}{l}\text { Mini- } \\
\text { mum }\end{array}$ & $\begin{array}{l}\text { Maxi- } \\
\text { mum }\end{array}$ & & an & $\begin{array}{c}\text { Std. } \\
\text { Deviation }\end{array}$ & Variance \\
\hline & Statistic & Statistic & Statistic & Statistic & Statistic & Std. Error & Statistic & Statistic \\
\hline Year & 72 & 14.00 & 2003 & 2017 & 2011.31 & 0.45 & 3.77 & 14.24 \\
\hline IFDI & 72 & 4246.26 & 77.21 & 4323.48 & 1069.61 & 115.50 & 980.07 & 960527.79 \\
\hline$\Delta \mathrm{IFDI}$ & 67 & 8.96 & -0.92 & 8.04 & 0.35 & 0.15 & 1.26 & 1.58 \\
\hline$\Delta$ IFDI_1 & 60 & 8.96 & -0.92 & 8.04 & 0.34 & 0.17 & 1.30 & 1.70 \\
\hline$\Delta$ IFDI_2 & 54 & 4.38 & -0.92 & 3.47 & 0.23 & 0.12 & 0.86 & 0.74 \\
\hline$\Delta$ IFDI_3 & 48 & 4.31 & -0.85 & 3.47 & 0.25 & 0.13 & 0.89 & 0.79 \\
\hline EMPL & 72 & 27.40 & 24.50 & 51.90 & 40.71 & 0.66 & 5.64 & 31.81 \\
\hline$\triangle \mathrm{EMPL}$ & 66 & 1.26 & -0.42 & 0.84 & 0.02 & 0.02 & 0.12 & 0.02 \\
\hline ANW & 72 & 596.65 & 205.54 & 802.19 & 430.11 & 18.34 & 155.63 & 24221.40 \\
\hline$\triangle \mathrm{ANW}$ & 66 & 0.49 & -0.16 & 0.34 & 0.04 & 0.01 & 0.07 & 0.01 \\
\hline $\begin{array}{l}\text { Valid N } \\
\text { (listwise) }\end{array}$ & 48 & & & & & & & \\
\hline
\end{tabular}

Source: Authors' calculation

where:

IFDI - Foreign Direct Investment Inflow in million EUR, $\triangle$ IFDI - Foreign Direct Investment Inflow change rate, $\Delta$ IFDI_1 - Foreign Direct Investment Inflow change rate after 1 year, $\Delta$ IFDI_2 - Foreign Direct Investment Inflow change rate after 2 years, $\Delta$ IFDI_3 - Foreign Direct Investment Inflow change rate after 3 years, EMPL - Employment rate, $\triangle \mathrm{EMPL}$ - Employment rate change rate, ANW - Average Net Wages in EUR, $\triangle \mathrm{ANW}$ - Average Net Wages change rate. The number of observations differed due to the lack of official data in some countries.

Variables such as GDP and population size are not included in the modelling for the following reasons. Unobserved heterogeneity (including that pertaining to the economy and population size) is captured by the country-specific random intercepts. In other words, due to the difference in population and GDP between countries, the percentage changes of the dependent variable were modelled, the reason why random effects at the country level were introduced.

The above-listed abbreviations for the variables are used in the next subsection.

\section{MODEL SPECIFICATION}

The model specification convention was based on Anderson (2013) and Heck, Thomas \& Tabata (2014). Linear mixed-effects models (LMM) are used to process the estimation of the overall impact of the changes in IFDI on the changes in the employment rate $(\triangle \mathrm{EMPL})$ and on the changes in average net wages $(\triangle \mathrm{ANW})$ in the Western Balkan economies in the period from 2003 to 2017. The changes in variables are measured in percentage points. LMM is often the preferred model because of its asymptotic efficiency (minimum variance), whether or not the data is balanced. 
The reason for choosing LMM (i.e., to include random effects in the models) is that the impact of independent variables on the dependent variable may differ from country to country. Ex post allows the effects of EMPL and of ANW to vary, the models include random intercepts as well. This is because each country has its own increasing or decreasing trend of EMPL and ANW. The models, therefore, contain fixed effects and random intercepts (level of dependent variables) and random slopes (for the $\Delta$ IFDI variable) for each country in the sample. LMM estimates the effect of $\Delta$ IFDI and lagged $\Delta$ IFDI on $\triangle \mathrm{EMPL}$ and on $\triangle \mathrm{ANW}$, while adjusting for correlation due to repeated observations on each variable over each year. Based on the theoretical assumption that IFDI requires time to show the real effects of performing in the country, the lagged terms were used. A typical assumption here is that the regression coefficients have normal distributions, and unstandardized coefficients (the coefficients are in their original metrics). In terms of likelihood ratio tests, the information criterion used to search for the best model fit is Akaike's Information Criterion (AIC). The Maximum Likelihood (ML) method is adopted because it allows inferences to be made on the covariance parameters of the model. The Hausman test is used to evaluate the consistency of the random effects in comparison with the fixed effects.

Data analysis was performed using IBM SPSS software (23) to in order to estimate the dependency amongst the changes in $\triangle \mathrm{IFDI}$ and both $\triangle \mathrm{EMPL}$ and $\triangle \mathrm{ANW}$ in the countries studied. All the chosen independent variables ( $\triangle$ IFDI, lagged $\triangle \mathrm{IFDI}$ ) explain the $\triangle \mathrm{EMPL}$ in model (1), and the $\triangle \mathrm{ANW}$ in model (2) in $t$ time for $i$ countries. Therefore, it is a matter of modelling the percentage changes in variables rather than modelling the values of the same variables because the changes are most efficiently represented by percentages. Indeed, differentials allow the model to capture the effects with greater certainty, rather than relations often biased or artificial. The authors' intention is to determine whether there is a quantitative relation between the dependent and independent variables, based on the following two models:

$$
\begin{aligned}
& \Delta \mathrm{EMPL}_{\mathrm{ti}}=\gamma_{00}+\gamma_{10} \Delta \mathrm{IFDI}_{\mathrm{t}}+\gamma_{20} \Delta \text { IFDI_1 }{ }_{\mathrm{t}}+\gamma_{30} \Delta \mathrm{IFDI} 2_{\mathrm{t}}+\gamma_{40} \Delta \text { IFDI_3 }{ }_{\mathrm{t}}+ \\
& \mu_{1 \mathrm{i}} \Delta \mathrm{IFDI}_{\mathrm{ti}}+\mu_{2 \mathrm{i}} \Delta \mathrm{IFDI} 1_{\mathrm{ti}}+\mu_{3 \mathrm{i}} \Delta \mathrm{IFDI} 2_{\mathrm{ti}}+\mu_{4 \mathrm{i}} \Delta \mathrm{IFDI} 3_{\mathrm{ti}}+\mu_{0 \mathrm{i}}+\varepsilon_{\mathrm{ti}} \\
& \Delta \mathrm{ANW}_{\mathrm{ti}}=\gamma_{00}+\gamma_{10} \Delta \text { IFDI }_{\mathrm{t}}+\gamma_{20} \Delta \text { IFDI_1 } 1_{\mathrm{t}}+\gamma_{30} \Delta \text { IFDI_2 }+\gamma_{40} \Delta \text { IFDI_3 }{ }_{\mathrm{t}}+ \\
& \mu_{1 \mathrm{i}} \Delta \mathrm{IFDI}_{\mathrm{ti}}+\mu_{2 \mathrm{i}} \Delta \text { IFDI_1 }{ }_{\mathrm{ti}}+\mu_{3 \mathrm{i}} \Delta \text { IFDI_2 } 2_{\mathrm{ti}}+\mu_{4 \mathrm{i}} \Delta \text { IFDI_3 } 3_{\mathrm{ti}}+\mu_{0 \mathrm{i}}+\varepsilon_{\mathrm{ti}}
\end{aligned}
$$

where:

$\gamma_{00}$ - grand intercept capturing the variation amongst $t$ in $i, \gamma_{n 0}$ - fixed effects across groups, $\mu_{0 i}-$ between-country variation in intercepts - deviation from the average intercept, $\mu_{n i}$ - random effects capturing variation in individual slope coefficients, $\varepsilon_{t i}$ individual-level residual in $t$ within $i . \Delta \mathrm{EMPL}_{\mathrm{ti}}$ - dependent variable in model (1), $\Delta \mathrm{ANW}_{\mathrm{ti}}$ - dependent variable in model (2), $\Delta \mathrm{IFDI}$ with its time lags ( $\triangle$ IFDI_1, $\Delta$ IFDI_2, $\Delta$ IFDI_3) for the six countries - independent variables (predictors). The model estimations are expressed in the annual growth rate.

The null hypothesis is that changes in both $\triangle \mathrm{EMPL}$ and $\triangle \mathrm{ANW}$ are not influenced by changes in $\triangle \mathrm{IFDI}$ and its time lags. Instead, the alternative hypothesis is that changes in both $\triangle \mathrm{EMPL}$ and $\triangle \mathrm{ANW}$ are influenced by changes in $\triangle$ IFDI and its time lags.

The next section presents the estimated results of the models applied. 


\section{EMPIRICAL RESULTS}

This section presents the results of the analysis described in the previous part of the paper. In this section, model 1 is shown as (1), and model 2 as (2).

The estimation was by LMM (between-groups and within-group estimation). Random effects, therefore, consider idiosyncratic qualifications of the units as non-observable and randomly distributed. The purpose of the models was to estimate the overall impact of the changes in $\triangle \mathrm{IFDI}$ on $\triangle \mathrm{EMPL}$ in (1) and on $\triangle \mathrm{ANW}$ in (2). Adding lags one by one to $\triangle \mathrm{IFDI}$, to a total of three, both the models show some positive impact after performing for some time. For both models, the dependent variable changes in time $t$ by a certain number of percentage points (not the percent rate), after taking into consideration the level of the changes in $\triangle$ IFDI and of the country in that and previous periods.

The first next step in this process was to control the outcomes of the Hausman test. The Hausman test confirms that the use of random effects is justified, i.e., that the random effects are consistent with the fixed effects. The second next step in this process was to control for the outcomes of AICs. The results from the Hausman test and AIC are presented in the Table 4.

Table 4. Hausman Test and AIC: Results

\begin{tabular}{lll}
\hline & $(1) \Delta \mathrm{EMPL}_{\mathrm{ti}}$ & $(2) \Delta \mathrm{ANW}_{\mathrm{ti}}$ \\
\hline \multirow{3}{*}{ Hausman test } & chisq $=0.018995$ & chisq $=0.56995$ \\
\cline { 2 - 3 } & $\mathrm{df}=5$ & $\mathrm{df}=5$ \\
\cline { 2 - 3 } & $\mathrm{p}$-value $=1$ & $\mathrm{p}$-value $=0.9893$ \\
\hline AIC & -114.301 & -194.038 \\
\hline
\end{tabular}

Source: Authors' calculation

Reassuring the smallest possible value of AIC followed by the theoretical and analytical logic, the models are accepted and presented in Tables 5 and 6 . Statistical significance was analysed using p-value as appropriate. Significance levels were set at the $5 \%$ level using the p-value.

Table 5. FDI Inflow Effects on Employment Rate (\% $\Delta$ )

\begin{tabular}{lccccccc}
\hline \multicolumn{7}{c}{ Estimates of Fixed Effects (a) } \\
\hline Parameter & Estimate & Std. Error & $\mathrm{df}$ & $\mathrm{t}$ & Sig. & 95\% Confidence Interval \\
\hline & & & & & $\begin{array}{c}\text { Lower } \\
\text { Bound }\end{array}$ & $\begin{array}{c}\text { Upper } \\
\text { Bound }\end{array}$ \\
\hline Intercept & 0.014 & 0.005 & 5.771 & 2.537 & 0.046 & 0.000 & 0.027 \\
\hline$\Delta$ IFDI & -0.005 & 0.005 & 11.631 & -1.178 & 0.263 & -0.016 & 0.005 \\
\hline$\Delta$ IFDI_1 & -0.001 & 0.002 & 9.259 & -0.449 & 0.663 & -0.005 & 0.004 \\
\hline$\Delta$ IFDI_2 & 0.021 & 0.006 & 5.046 & 3.577 & 0.016 & 0.006 & 0.036 \\
\hline$\Delta$ IFDI_3 & 0.030 & 0.004 & 6.232 & 7.718 & 0.000 & 0.021 & 0.040 \\
\hline
\end{tabular}

(a) Dependent Variable: $\triangle$ EMPL. 
For the estimation of the impact of $\triangle$ IFDI on $\triangle E M P L$, the (1) was used, represented in Table 4. The effect of $\Delta$ IFDI shows a small negative impact in the same year when IFDI occurs, but there is no statistical certainty of that because $\mathrm{p}=0.263$ and the interval of confidence is between negative $(-0.016)$ and positive (0.005) values. This is in line with the prevailing economic literature, which suggests that foreign investments require time to show their effects in the host country. In fact, after one year of IFDI performance (IFDI_1) there is almost null impact on $\triangle \mathrm{EMPL}(-0.001, \mathrm{p}=0.663)$, leading to the positive impact in the next periods. Model (1) shows $0.021 \%(\mathrm{p}=0.016)$ increase in $\triangle \mathrm{EMPL}$ for each additional unit of change in $\triangle$ IFDI after two ( $\triangle$ IFDI_2) years of IFDI performance. The strongest positive effect is represented by the $\triangle$ IFDI_3, meaning that for the double increase in IFDI in time there would be a $0.03 \%(\mathrm{p}=.000)$ increase in $\triangle \mathrm{EMPL}$ after 3 years of foreign investment performance in the country $i$. The model suggests that the greater the foreign investment, the faster the growth in employment rate in Western Balkan countries. This statement is in accordance with the theoretical and empirical assumptions that there is more room for growth and faster employment increase (unsaturated labour market) in transition countries.

Table 6. FDI Inflow Effects on Average Net Wages (\% $\Delta$ )

\begin{tabular}{lccccccc}
\hline \multicolumn{7}{c}{ Estimates of Fixed Effects (a) } \\
\hline Parameter & Estimate & Std. Error & $\mathrm{df}$ & $\mathrm{t}$ & Sig. & 95\% Confidence Interval \\
\hline & & & & & $\begin{array}{c}\text { Lower } \\
\text { Bound }\end{array}$ & $\begin{array}{c}\text { Upper } \\
\text { Bound }\end{array}$ \\
\hline Intercept & 0.007 & 0.001 & 28.113 & 6.177 & 0.000 & 0.005 & 0.009 \\
\hline$\Delta$ IFDI & 0.013 & 0.013 & 4.598 & 0.946 & 0.391 & -0.023 & 0.048 \\
\hline$\Delta$ IFDI_1 & 0.010 & 0.001 & 3.407 & 7.138 & 0.004 & 0.006 & 0.015 \\
\hline$\Delta$ IFDI_2 & 0.008 & 0.002 & 66.702 & 3.405 & 0.001 & 0.003 & 0.013 \\
\hline$\Delta$ IFDI_3 & 0.005 & 0.005 & 4.006 & 0.911 & 0.414 & -0.009 & 0.019 \\
\hline
\end{tabular}

(a) Dependent Variable: $\triangle \mathrm{ANW}$.

\section{Source: Authors' calculation}

For the estimation of the impact of the $\triangle \mathrm{IFDI}$ on $\triangle \mathrm{ANW}$, the (2) was used, represented in Table 5. Model (2) presents an increase in $\triangle \mathrm{ANW}$ due to $\triangle \mathrm{IFDI}$ in the observed period. The significant impact of the changes in $\triangle$ IFDI on $\triangle \mathrm{ANW}$ is positive and after one $(0.010, \mathrm{p}=0.004)$ and after two $(0.008$, $\mathrm{p}=0.001$ ) years of its performance. The model suggests that the foreign investment impacts, even if in a very small measure, the increase in ANW in Western Balkan countries. In terms of the greater impact, if foreign investments double in time $t$ in country $i$, after one year the average growth rate of $\triangle \mathrm{ANW}$ will be $0.01 \%$. The effect of the changes in $\triangle \mathrm{IFDI}$ appear to be positive in all the periods of observation, but there is no statistical significance in the period of FDI entrance and after three years of its performance in the country $i$. This last allows the statement that there is a constant low positive effect of IFDI on ANW in Western Balkan countries.

In both the models, there is a positive growth rate in all six countries, and not for the entire period in case of the impact of the changes in IFDI on the changes in employment rate, meaning that the null hypothesis is rejected. 


\section{DISCUSSION}

The empirical section of the paper adds to the results of earlier empirical studies with the finding that FDI inflow has a positive effect on the employment rate and on average net wages in Western Balkan representative countries. Foreign capital, in this case FDI inflow, slightly increases both the employment rate and average net wages in the long term. Surely, foreign capital requires time to show its effects on the labour market, which is why the application of lags is justified.

The findings of this investigation complement those of some earlier studies. As concerns average net wages, the findings of this research are consistent with Bhandari (2007) and Kurtovic et al. (2015), authors who applied OLS regression estimation instead of LMM. As for the impact of FDI inflow on employment, Jude \& Silaghi (2016) would provide an effective comparison with this research if the authors had used FDI inflow instead of FDI stock, because both the analyses claim the positive long-term effect on employment. The findings of this paper partially confirm the findings of Domazet (2016) as well, while disagreeing with Peric (2019), presumably because of the larger sample used in this research.

FDI inflow showed a positive, if very low, impact on the examined labour market indicators. Although all six economies have experienced many changes on the economic level, they can be differentiated from one each other, in terms of their higher or lesser employment rate and average net wages. There is reason to believe that FDI inflow is not the sole reason for this, because Serbia, as the biggest importer of FDI among the six countries, has much lower average net wages than Croatia. Perhaps the developing countries in economic transition should look at neighbour's economic strategies (such as Slovenia, Czech Republic, etc.) as well as thoroughly investigating the FDI inflow options before adopting it, for example, attracting FDI in high-tech sectors and strong HRM (human resource management).

Moreover, regional collaboration should be strengthened in order to stimulate foreign companies to invest and to communicate with the region. Finally, it is recommended to study how to attract investors that pay higher wages, which involves further studying the availability and skills of host country employees and any potential brain drain. The focus on increasing the level of employment should be replaced with the focus on the structural level of employment. Lastly, it is recommended to enhance the efficiency and competitiveness of the national economy along with the companies through the implementation of strategies in order to solve employment and wage problems. Recommendations for the Governments are to re-evaluate FDI existing approach, such as decreasing subventions and investing in education. Large companies should invest in HRM, while small and micro firm should learn and promote HRM and business ethics.

A further increase in FDI to the Western Balkan countries could be promising with more adequate development policies, which require deep institutional reforms and political consciousness and responsibility. 


\section{CONCLUSIONS}

This paper has argued that the FDI inflow should enhance growth in the employment rate and in average net wages in the host country. This research empirically estimated the impact of the changes in FDI inflow on the changes in the employment rate and in average net wages in the Western Balkan area representative countries for the period 2003-2017. Linear mixed-effects models have revealed the existence of a very low but still positive impact of FDI inflow on both the labour market indicators used here:

a) changes in IFDI effect the positive changes in employment rate after the second and the third year of IFDI performance in the country $i$;

b) changes in IFDI effect the changes in average net wages mainly after the first and the second year of IFDI performance in the country $i$.

The generalisability of these results is subject to certain limitations. Since there is little empirical evidence of the impact of FDI inflow on the main labour market indicators in transition countries, this paper offers findings to stimulate further research. In the first place, further data collection is required to determine exactly how FDI affects labour market. In the second place, it is recommended that more countries should be included in the model. Notwithstanding the relatively limited sample, this work offers valuable insights into the FDI inflow impact on labour market main indicators. However, in order to estimate the impact of FDI inflow in each individual country, one could conduct single multiple regressions to estimate the supposed impact of FDI inflow on the employment rate and on average net wages. Estimating the FDI spill-overs in each individual country may contribute to investigation of the FDI inflow time effects over the different sectors (service, industry, agriculture). The distinction between sectors may be relevant because there is reason to believe that the effect of FDI inflow is not equal for all six countries.

\section{REFERENCES}

Anderson, C. J. (2013). Longitudinal Data Analysis via Linear Mixed Model. Department of Educational Psychology, University of Illinois, Urbana Champaign. USA. Unpublished.

Bartlett, W. (2007). Economic Transition in Serbia since 2000: Trends and Prospects. Journal of the Western Balkans Security Observer, 7-8, 29-37.

Bhandari, B. (2007). Effect of Inward Foreign Direct Investment on Income Inequality in Transition Countries. Journal of Economic Integration, 22(4), 888-928.

Bitzenis, A., \& Marangos, J. (2007). Globalization and the Integration-Assisted Transition in Central and Eastern European Economies. Journal of Economic Issues, 41(2), 427-434. doi: 10.1080/00213624.2007.11507030

Brada, J. C., Kutan, A. M., \& Yigit, T. M. (2006). The effects of transition and political instability on foreign direct investment inflows: Central Europe and the Balkans. Economics of Transition, 14(4), 649-680.

Bukowski, C. (2005). Slovenia'a Accession to the European Union: Domestic and Foreign Policy Consequences. Slovene Studies Journal, 25(1-2), 63-69.

Chandler, D. (2007). From Dayton to Europe. International Peacekeeping, 12(3), 336-349. doi: $10.1080 / 13533310500074077$

Dabla-Norris, E., Honda, J., Lahreche, A., \& Verdier, G. (2010). FDI Flows to Low-Income Countries: Global Drivers and Growth Implications. IMF Working Paper WP/10/132.

Domazet, A. (2016). Foreign direct investment in Bosnia and Herzegovina: From the delusions of neoliberalism to drivers of economic growth. Posebna izdanja Akademije nauka i umjetnosti BiH, 2, 126-145. 
Driffield, N., Girma, S., Henry, M., \& Taylor, K. (2010). Wage inequality, linkages and FDI. IZA Discussion Paper No. 4722.

Estrin, S., \& Uvalic, M. (2013). Foreign direct investment into transition economies: Are the Balkans different? LEQS Discussion paper No. 64/2013.

Figini, P., \& Gorg, H. (2006). Does foreign direct investment affect wage inequality? An empirical investigation. IZA Discussion Paper No. 2336.

Gopinath, M., \& Chen, W. (2003). Foreign direct investment and wages: a cross-country analysis. Journal of International Trade \& Economic Development, 12(3), 285-309. doi: 10.1080/0963819032000132067

Grahovac, D., \& Softic, S. (2017). Impact of the FDI on Unemployment rate in countries of West Balkan. Review of innovation and competitiveness, 3(2), 65-82.

Hadzic, M., \& Pavlovic, P. (2011). How to Overcome (SME) Crisis: Serbian Case. Acta Polytechnica Hungarica, 8(1), 61-80.

Hale, G., \& Xu, M. (2016). FDI effects on the labor market of host countries. Federal Reserve Bank of San Francisco Working Paper 2016-25. Retrieved from: http://www.frbsf.org/economic-research/files/wp2016-25.pdf

Halmos, K. (2011). The Effect of FDI, Exports and GDP on Income Inequality in 15 Eastern European Countries. Acta Polytechnica Hungarica, 8(1), 123-136.

Heck, H. R., Thomas L. S., \& Tabata, N. L. (2014). Multilevel and Longitudinal Modeling with IBM SPSS. Routledge, New York and London.

Jude, C., \& Silaghi, I. P. M. (2016). Employment effects of foreign direct investment: New evidence from Central and Eastern European countries. International Economics, 145, 32-49.

Kekic, L. (2006). Foreign direct investment in the Balkans: recent trends and prospects. Southeast European and Black Sea Studies, 5(2), 171-190. Doi. 10.1080/14683850500122687

Kekic, L. (2011). The global economic crisis and FDI flows to emerging markets. In Karl P. Sauvant, Lisa Sachs, Kenneth Davies, and Ruben Zandvliet (eds.), FDI perspectives: Issues in international investment (2-6). New York: Vale Columbia Center on Sustainable International Investment.

Krammer, S. M. S. (2010). International R\&D spillovers in emerging markets: The impact of trade and foreign direct investment. Journal of International Trade and Economic Development, 19(4), 591-623. doi: $10.1080 / 09638190902792464$

Kurtovic, S., Talovic, S., \& Dacic, L. (2015). Panel cointegration analysis of Foreign Direct Investments and Average Net Wages: The case of four Western Balkan Countries. G. \& L. E. R. 19(1), 1-36.

Melnyk, L., Kubatko, O., \& Pysarenko, S. (2014). The impact of foreign direct investment on economic growth: case of post communism transition economies. Problems and Perspectives in Management, 12(1), 17-24.

Neto, P., Brandao, A., \& Cerqueria, A. (2008). The impact of FDI, Cross Border Merger and Acquisitions and Greenfiled Investments on Economic Growth. Journal of Business Strategy, 7(4), 24-44.

Nikolic, D., \& Bodroza, D. (2012). Positioning and re-positioning of national brand of Serbia in order to increase exports, foreign direct investments and tourism development. In Joao S. Andrade, Marta C. N. Simoes, Ivan Stosic, Dejan Eric, Hasan Hanic (eds.), Managing Structural Changes: Trends and Requirements (488-505). Belgrade: IES.

OECD. (2008). OECD Benchmark Definition of Foreign Direct Investment, $4^{\text {th }}$ edition. OECD.

Peric, M. (2019). Impact of FDI inflow on employment and average wage in Serbia. Management: Journal of Sustainable Business and Management Solutions in Emerging Economies, forthcoming. doi: 10.7595/management.fon.2019.0007

Peric, M., \& Filipovic, S. (2018). The impact of the determinants of export on the export in the Republic of Serbia. Industrija, 46(2), 151-171. doi: 10.5937/industrija46-17408

Pitic, G., Savic, N., Barjaktarovic, L., \& Konjikusic, S. (2014). The impact of different forms of Foreign Capital Inflow on GDPpc in CEE Countries during the Crisis up to 2012. Eurasian Journal of Economics and Finance, 2(2), 70-77. doi: 10.15604/ejef.2014.02.02.006 
Popovic, G., \& Eric, O. (2018). Economic development of the Western Balkans and European Union investments. Economic Research, 31(1), 1539-1556. doi. 10.1080/1331677X.2018.1498009

Sabic, D., Vujadinovic, S., Milincic, M., Golic, R., Stojkovic, S., Joksimovic, M., Filipovic, D., \& Secerov, V. (2012). The Impact of FDI on the Transition Economy in Serbia - Changes and Challenges. Acta Polytechnica Hungarica, 9(3), 65-84.

Savic, N., Barjaktarovic, L., \& Konjikusic, S. (2014). Foreign Capital Inflow and GDPpc in CEE Countries. Actual Problems of Economics, 3(153), 54-65.

Stanisic, N. (2008). Do Foreign Direct Investments increase the economic growth of Southeastern European Transition Economies? South-Eastern Europe Journal of Economics, 42(1), 29-38.

Szondi, G. (2007). The role and challenges of country branding in transition countries: The Central and Eastern European experience. Place Branding and Public Diplomacy, 3(1), 8-20. doi: 10.1057/palgrave.pb.6000044

Tanna, S., Li, C., \& De Vita, G. (2018). The role of external debt in the foreign direct investment-growth relationship. International Journal of Finance and Economics, 23(4), 393-412. doi: 10.1002/ijfe.1628

Taylor, K., \& Driffield, N. (2005). Wage Inequality and the Role of Multinationals: Evidence from UK Panel Data. Labour Economics, 12(2), 223-249. doi: 10.1016/j.labeco.2003.11.003

UNCTAD. (2011). World Investment report: Non-Equity Modes of International Production and Development. New York and Geneva: UN.

UNCTAD. (2018). World Investment Report: Investment and new industrial polices. New York and Geneva: UN.

Vesaite, R. (2014). FDI from European Union to Western Balkan Countires: is the economic development being intensified in the region? Institut Universitari d'Estudis Europeus.

Todorova, S. M. (2018). Foreign Investment Inflows to Former Socialist Countries in the Balkans: Mapping Global Capitalism. Interventions: International Journal of Postcolonial Studies, 20(6), 814-831. DOI: 10.1080/1369801X.2018.1492953

Zdravkovic, A., \& Martinovic, B. A. (2016). To which extent did the FDI contribute to employment growth in transition countries? In International Scientific Conference: Impact of Economic Policies on Attaining Resilient Growth, October 27 $7^{\text {th }}$, Belgrade.

Zulfiu, M. A. (2014). Simulation Analysis of the Effects of Increased Foreign Ownership on Wage. Academicus International Scientific Journal, 9, 140-158. doi: 10.7336/academicus.2014.09.10 


\section{UTICAJ PRILIVA SDI NA TRŽIŠTE RADA ZAPADNOG BALKANA}

\section{Rezime:}

Zavisnost tržišta rada od priliva stranih direktnih investicija (SDI) veoma je visoka u ekonomijama u tranziciji. Ovaj rad se bavi procenom uticaja koji priliv SDI ima na stopu zaposlenosti i prosečne neto zarade u ekonomijama Zapadnog Balkana u periodu 2003-2017. Date ekonomije su uzete kao uzorak (Albanija, Bosna i Hercegovina, Hrvatska, Severna Makedonija, Crna Gora i Srbija) uglavnom zbog velikog nasleđa u vidu SDI i nezasićenog tržišta rada. Pretpostavlja se da priliv SDI pozitivno utiče na stopu zaposlenost kao i na prosečne neto zarade u zemljama Zapadnog Balkana. Koristeći linearne mešovite modele (LMM), rezultati pokazuju da promene priliva SDI imaju vrlo niske, ali pozitivne i značajne efekte kako na promene stope zaposlenosti, tako i na prosečne neto zarade.
Ključne reči: prosečna neto zarada, stopa zaposlenosti, strane direktne investicije, linearni mešoviti modeli, slučajni efekti. 